\title{
Paideusis
}

\section{The Limits of Reason: Indeterminacy in Law, Education, and Morality (John A. Eisenberg)}

Frederick S. Ellett, Jr.

Volume 7, Number 2, 1994

URI: https://id.erudit.org/iderudit/1073282ar

DOI: https://doi.org/10.7202/1073282ar

See table of contents

Publisher(s)

Canadian Philosophy of Education Society

ISSN

0838-4517 (print)

1916-0348 (digital)

Explore this journal

Cite this review

Ellett, Jr., F. (1994). Review of [The Limits of Reason: Indeterminacy in Law, Education, and Morality (John A. Eisenberg)]. Paideusis, 7(2), 29-33.

https://doi.org/10.7202/1073282ar

This document is protected by copyright law. Use of the services of Erudit (including reproduction) is subject to its terms and conditions, which can be viewed online.

https://apropos.erudit.org/en/users/policy-on-use/ 


\section{Critical Review}

John A. Eisenberg, The Limits of Reason: Indeterminacy in Law, Education, and Morality Toronto: Ontario Institute for Studies in Education, 1992.

Eisenberg provides several educational examples to show that the (unintended) consequences of certain programs and policies, programs which lawyers, politicians, and educators have put in the name of "reason" (or "rationality") have been rather bad. In many cases, the intended goals themselves were not even achieved. Eisenberg seems to grasp that the failures which occur in the name of reason have little to teach us about the limits of reason unless the agents are trying to act according to some account (or "model") of rationality (70-71, 78-79). Yet, as Eisenberg himself admits, in many of the cases, the agents were not acting rationally at all. Here, perhaps, it is important to find out how these people could fool so many (including themselves?) so much of the time. One might expect that some understanding of this "fraud" would help us deal with it.

But Eisenberg does not pursue these matters because he is really trying to show that, even if they were rational, the outcomes would not be, it seems, appreciably better. If the "advance reviews" are any indication, iEisenberg's pessimistic view of rational, social change appears to be the dominant theme of the book. I want to suggest, however, that Eisenberg is also trying to develop a relatively "less-pessimistic" view of social change. Furthermore, I want to show that, given Eisenberg's deepest philosophical views, he is committed to a more hopeful view of social practices and reason itself.

Let me begin by showing he has two different views about (educational) change. The first view-the one that fixes the tone of the book-is strongly pessimistic about anything sensible (or rational) occurring in any kind of social institution. Eisenberg provides two types of support for this view. The first type is drawn from a view of "rationality," the second, from Goffman's work (1962) on mental institutions and Illich's work (1972) on the hidden structures of schools. Here is Eisenberg's summary of the (kinds of) conclusions to be drawn:

Moral education programs in the schools are either futile or severely limited because:

(a) The structure of the school, especially the implicit power relationships, is a morality in itself, quite apart from the stated morality of the school, and almost always takes precedence over the stated morality; and

(b) The content of the morality in moral education programs is in conflict with the powerful content of the dominant content of the major institutions of our society. Thus there is a pervasive indeterminacy in social practices, in the sense that we cannot determine our own ends deliberately and rationally. (44)

This sense of "indeterminacy" is concerned, at least, with our inability to grasp fully the nature of our institutions and to control completely the outcomes (149); but it is also concerned with our inability to control in any significant way our institutions (34-44, 172-3). I believe that Eisenberg's reliance on Goffman and Illich to support the second half of the claim-that our efforts are (nearly) always 
futile-is unconvincing, in part, because such work is limited and dated. A more adequate account of these matters should consider the work done by Hodgkinson (1991) and Greenfield (1979-80). At any rate, the proper degree of "caution" appropriate to deal with institutional change is a complex matter that depends in a fundamental way on our best [empirical] theories about institutions:

A more hopeful view involves his own view of reasoning, the strategic reasoning model (SRM) (69-81). As he says, "[t]he examples [of the SRM] presented and analyzed are meant to indicate there is a common rational way of dealing with social problems" (78). Here he says nothing to indicate that our efforts are doomed to futility. He does claim that reason is limited because it can not solve unsolvable problems (78). To see this as a limit, as Eisenberg suggests, is to embrace the rationalist view of a method. But the defence of rational approaches does not, and cannot, show they will solve every problem. The defence has a more modest form: we have nothing better to rely on than rational approaches (see Black, $1972 \& 1975$ and Rescher, 1988). Note that what is unsolvable is itself a theoretical judgement, one open to revision (see Margolis, 1986, Chapter 2). In another place, Eisenberg claims that (the old kind of?) rationality involves some kind of calculation and that it does not involve intuition (172). He also claims that "rationality is not simply an active mode. . .it may also be an ingredient in social reality, itself determined [in some sense] by other forces" (172). Again, these kinds of criticisms work well, I believe, against the rationalist. Is there a more adequate account of reason?

The shock value of the book is largely due to the way Eisenberg uses the key terms. Thus, he seems to take "control" to mean "total and complete control" (here one is reminded of the ways B.F. Skinner, the well-known logical empiricist, used the term "control.") He seems to take "knowledge" to mean "knowledge capable of precise prediction" (see 1-2). If one thinks that these terms have distinct and more "modest" uses, then Eisenberg's "conclusions" appear to be true but uninteresting.

Let me illustrate, in some detail, how Eisenbeng's talk about "reason" leads us in the wrong direction. Eisenberg himself claims to be concerned with this deep matter: the very limits of reason (or rationality). At the start, he says he intends to oppose the view held in common by Plato, Aristotle, Bacon, Laplace, Spinoza, Gassendi, Leibniz, and many others (2). (He explicitly singles out Thomas Aquinas, but mentions neither Descartes nor Kant!)

What appears to be a common epistemic view held by these notable philosophers is rationalism. Rationalism holds that "knowledge $=$ ssource $\}+$ \{logic\}." All such sources must yield an infallible (or certain), intuitive knowledge-base (or foundation) upon which all other knowledge is built by way of logical transitions. Logic is, of course, identified with the universal, a priori, and fixed laws that govern thinking. Many rationalists, but not all, have held that the real world itself is governed by universal laws. (For Kant, physical nature is governed by physical laws, while a person's (free) reasoning capacity is governed by the universal laws of thought.)

Eisenberg fails to point out that the empiricists also held that "knowledge $=\{$ source $\}+\{$ logic $\} . " F o r$ the classical empiricists, the "source" was some kind of "sense-data"; the logical empiricists eventually took the "source" to be "observational-data" and expanded logic to include not only deductive but also 
inductive (or probabilistic) reasoning. Although the empiricists have come to accept probabilistic-claims, they still hold that "knowledge $=$ \{source\} + \{formal logic\}" (see Hooker, 1987). For many empiricists, the real world itself was governed by "universal" regularities. But there was much disagreement about whether we could ever know enough of these regularities to be able to change the social world in any interesting way. Eisenberg means to oppose this view of the social world, for he claims to know (without too much argument) that the social world is indeterminate (in certain ways).

Nonetheless, it is the view of knowledge, the view held by the empiricist and rationalist alike, which has enabled people to draw a sharp line between knowledge (the "facts") about the world and those domains of inquiry within which values might play a role. This view underpins the strong fact/value distinction, which it appears that Eisenberg himself accepts (69-70). Such a view of knowledge takes science as firm or determinate and regards moral (or social inquiry) as unfirm, or indeterminate, or generally unreliable. The subtille of the book suggests this kind of demarcation between factual knowledge and the socio-political modes of inquiry. Here, Eisenberg seems quite close to the position recently advanced by Williams (1986).

But if one rejects both rationalism and empiricism, as I think Eisenberg really wants to do, then a plausible, alternative account of "knowledge" is needed. Let me assert all too quickly that it includes no foundations and no fixed, universal-rules (that is, no rule-foundations). It is opposed to all kinds of a priori philosophy. (And, so, it rejects views such as those recently put forward by Siegel, 1992.)

The account allows that the key concepts and the central rules of thought evolve and change to adapt to the ongoing inquiry. It sees security (the search for highly probable theories) as only one epistemic-value, a value that might conflict with the value for theories that are deeply informative (or explanatory). One has no recipe for making the trade-off judgments; one has to rely upon one's intuitions (which have been formed by one's past experiences). In short, the rational acceptance of scientific theories is a kind of practical rationality.

In this new view, rational inquiry allows for revision and change in all aspects of the scientific enterprise. Fallibilism (or revisability) becomes the central feature of the epistemology. Can it be shown that science is the best way to get truth about the world? No. There are no guarantees even here: as best we can judge, our best theories are to be trusted, but all are open to revision. (See Rescher, 1988, Chapter 3.)

So far, I have not mentioned one key feature. Unlike the rationalist (and the empiricist) for whom inquiry is basically an individualistic enterprise, the new account sees all inquiry (including physical and social inquiry) as basically a social activity, or a social practice. And though, as Popper has long maintained, the direction of the growth of knowledge is not predictable, inquiry is, nonetheless, a rational activity because the acceptance of theory is under the control of public concepts and criteria. For this view, "intersubjective agreement" is neither necessary nor sufficient for the rational acceptance of a theory (see, for example, Rescher, 1988 and Scheffler, 1986). Nor is there a guarantee that inquiry will produce a theory that uniquely satisfies the epistemic criteria. As Quine (1992, Section 41-43) has pointed out, there is a kind of deep-indeterminacy in theory acceptance itself. Although scientific inquiry is 
not totally controllable, it has enough control at its disposal to develop what we judge to be "acceptable" (and "reliable") theories about the (social) world. Indeed, the claim that the social world is indeterminate is just a famous example of an intelligible and reasonable theory about the world.

Although it is beyond the scope of this review to show it, this account of the form of theoretical reason looks much like Eisenberg's own strategic reasoning model. The ongoing rational inquiry of modern science has striking similarities to strategic reasoning. We can now see, therefore, that if one draws invidious comparisons between the moral-social and the scientific domains, then one eventually undermines the legitimacy of one's own knowledge-claims.

I suggest that Eisenberg needs to and will "develop" his epistemological views-he cites only Godel and Heisenberg-along the lines of the new view outlined above. Indeed, as I have suggested above, his own view ("strategic reasoning") is remarkably similar to what I take to be our best account of theory acceptance. When Eisenberg's criticisms are reorganized, they are telling against the rationalist (and even the empiricist) view. But the new view of rationality is not to be judged by rationalistic standards. And its defence is modest: there is, as best we can judge, nothing better to do than to follow rationality. Whether we should call "the best we have got" limited depends upon whether one is still haunted by rationalism!

In reorganizing his ideas and claims, Eisenberg will have to retract the claim that "one of the most influential proponents of rationalism. . .was John Dewey" (171). The first philosopher to object to the (Kantian?) view that nature is governed by universal, exceptionless laws was Peirce (in the early 1880s). Peirce tried to show that the world itself was govemed by chance and that our maxims of thought evolve during the inquiry. And Dewey was among the first to grasp the deep significance of Peirce's point (see Hacking, 1990.) In many places, Dewey explained that he used the term "intelligence" (in place of the term "reason") in part to distinguish his views from those of the rationalists $(1948$, viii.). But later thinkers can use, and have used, the term "rational" in its updated sense (see, especially, Black, 1972 \& 1975, Rescher, 1988, and Scheffler, 1986).

Part of Eisenberg's difficulty in appreciating Dewey stems from his accepting Collingwood's conception (1946) of science as eliminative physicalism (24-6). But Dewey never accepted either eliminative or reductive physicalism; and Dewey's views about historical-cultural inquiry are strikingly close to Collingwood's views. Eisenberg suggests that "informal empathy, intuition, and imagination" (25) are somehow at odds with reasonable or sensible inquiry. I think that neither Collingwood nor Dewey would accept such a claim (see, also, Black, 1975, Part II, Pt.1). Although these views are important steps forward in understanding persons as historical-cultural beings, I believe that Gadamer (1975) provides deeper insights (see, also, Margolis, 1989, Chapters 6 and 8).

Collingwood's work was, of course, concerned with the philosophical issues in the 1930s and 1940s. And though it is hard to get a sense of movement (progress?) in philosophy, there is a growing consensus by major philosophers that the mental terms are not eliminable but are "indispensable both to the social sciences and to our everyday dealings" (Quine, 1992, 73).

In modern form, "the new view" is called pragmatism. Its ablest ad- 
vocates are Hooker (1987), Margolis $(1986,1987)$, Rescher (1988), and Scheffler (1986).

Reviewed by Frederick S. Ellett, Jr., University of Western Ontario

Acknowledgment: I would like to thank J. Martin for helpful comments on this review.

\section{References}

Black, M. (1975). "Rationality and Cultural Relativity." In M. Black [Ed.]. Problems of Choice and Decision. Ithaca, N.Y.: Cornell University Program on Science, Technology, and Society, 128-160.

Black, M. (1972). "Reasonableness." In Dearden, R.F., Hirst, P.H., and Peters, R.S. [Editors]. Education and the Development of Reason. Part II: Reason. London: Routledge and Kegan Paul, 44-57.

Collingwood, R.G. (1976/1946). The Idea of History. Oxford: Oxford University Press.

Dewey, J. (1957/1948). Reconstruction in Philosophy (Enlarged Edition). Boston: Beacon Press.

Gadamer, H-G. (1975). Truth and Method. (Translated by G. Barden and R. Cumming from the 2nd German edition). New York: Seabury Press.

Goffman, E. (1961). Asylums: Essays on the Social Situations of Mental Patients and Other Inmates. Harmondsworth: Penguin Books.

Greenfield, T.B. (1979-80). "Research in Educational Administration in the United States and Canada: An Overview and Critique," Educational Administration, 8(1), 207-45.

Hacking, I. (1990). "A Universe of Chance." In I. Hacking, The Taming of Chance. Cambridge: Cambridge University Press. Chapter 23, 200-215.

Hodgkinson, C.A. (1991). Educational Leadership: The Moral Art. Albany, NY: State University of New York.

Hooker, C.A. (1987). A Realistic Theory of Science. Albany, N.Y.: State University of New York.

Illich, I. (1972). Deschooling Society. New York: Harper and Row.

Margolis, J. (1986). Pragmatism Without Foundations: Reconciling Realism and Relativism. Oxford: Basil Blackwell.

Margolis, J. (1987). Science Without Unity: Reconciling the Human and Natural Sciences. Oxford: Basil Blackwell.

Margolis, J. (1989). Texts Without Referents: Reconciling Science and Narrative. Oxford: Basil Blackwell.

Quine, W.V. (1992). Pursuit of Truth (Revised Edition). Cambridge, MA: Harvard University Press.

Rescher, N. (1988). Rationality. Oxford: Clarendon Press.

Scheffler, I. (1986). Inquiries. Indianapolis, IND: Hackett.

Siegel, H. (1992). "The Limits of A Priori Philosophy." Studies in Philosophy and Education, 11(3), 265-284.

Williams, B. (1985). Ethics and the Limits of Philosophy. Cambridge, MA: Harvard University Press. 